PRODUCTION

ENGINEERING

ARCHIVES
2015, Vol. 8, No. 3, pp 10-13

ISSN 2353-5156

ISSN 2353-7779 (print version)

(online version)
Article history: Received: $15.09 .2015 \quad$ Accepted: 22.09.2015

Online: 30.09 .2015

\title{
Achieving higher efficiency of produc- tion through knowledge management via social capital management
}

\author{
Jana Plchová, ${ }^{1}$ L'uboš Polakovič ${ }^{2}$ \\ ${ }^{1}$ Institute of Management of the Slovak University of Technology, Vazovova 5, Bratislava, Slovakia, phone +421918669141 , \\ e-mail: jana.plchova@stuba.sk \\ ${ }^{2}$ LOTES Centrum, Spiral Management Institute. Studenohorská 42, 84103 Bratislava, phone +421905315000 , \\ e-mail: lubos.polakovic@lotescentrum.com
}

\begin{abstract}
The article shows a new approach - how to reach higher efficiency in the production from knowledge management via managing social capital through measurement, motivation and stimulation. The test in a real company on the Toyota system implementation is described. The active involvement of people is an important part of the Toyota system success. This is obvious in Japan but creates a big problem in Europe. These problems were tested in order to answer the following questions: 1. Is it possible to measure the social system level before the application of the system?, 2. Is it possible to evaluate the necessary level of the social system for successful implementation in advance?, 3. Is it possible to cultivate the social system to the desired level? We try to answer all of these questions adopting the Kopčaj Spiral Management approach. The practical results on an existing company are presented together with managerial recommendations.
\end{abstract}

Key words Spiral management, Prigogine laws, social system measurement, entropy

\section{Introduction}

According to internal surveys in the Czech Republic and Slovakia, weak employee engagement is currently a major cause of failure in implementing systems to improve performance. The management of social capital in the implementation of these systems appears to be crucial, but management of people is often poorly implemented in the companies (DĚDKOVÁ, J., SRbKovÁ, D. 2013), (ŠÚbertovÁ, E. 2014), (ZATrochovÁ, M., HERZKA,P.,2011).

In this work we used an original management approach - Spiral management by Andrej Kopčaj. Spiral management is based on the philosophy of understanding the company as a living organism. Spiral management allows companies to quantify and therefore manage not only the area of knowledge and technologies in the company, but so far unquantifiable area of human capital management.

\subsection{Spiral management $-\mathbf{a}$ new approach to corporate management}

Spiral management brings a completely new approach to management. It focuses on the potential of the company. This allows to manage the company even in a turbulent environment. It is based on the fact 
that the company is composed of two systems technical - a non-living system (technology and knowledge in the company) and a social - living system (people in the company). Each of these systems is subject to different laws of nature and this fact must also be respected in their management.

The technical system is subject to the laws of thermodynamics. According to them, the following applies to each closed system:

1. The power of its internal environment is constant,

2. The entropy of the indoor environment just increases,

3. The limit of system state is the probability of entropic 1 (system malfunction).

The social system is based on the dynamics of systems interacting with the environment. According to I. Prigogine, the condition for the existence of the living, open system is its ability to:

1. gain energy from the outside,

2. discharge entropy in the external environment,

3. increase its level of complexity in the critical increase of entropy - thus evolve. (KOPČAJ A. 2007)

\subsection{Measurement of the entropy}

The Spiral Management uses entropy to describe the state of the company, because it can be used to describe the living and also non-living systems. Entropy reduction in the company is increasing the competitiveness and ensures its long-term and financially successful existence. The higher the entropy in the system, the less this system is capable of performing work. (KOPČAJ A. 2007)

We define entropy as a non-recoverable fraction of energy. The following applies to the total potential:

$\mathbf{p}_{\mathrm{c}}=\mathbf{1}-\mathbf{e}_{\mathrm{c}}$

$p_{c}$........ total potential,

$e_{c}$........ total entropy

Competitive company potential is then divided into two parts - technical and social potential. Unique to this approach is that the potential defined in this way can be measured by a single variable - entropy. (KOPČAJ A. 2007)

Manage system means:

1. identify its initial state,

2. define the desired target state
3. use the tools by which it is possible to manage systems from the initial state towards achieving the target state.

This basic management principle is widely accepted in the management of technical systems. However, present practice in management has not been enabled to apply it in the social systems management, since there was no clear measurable parameter by which it would be possible to quantify the state of the system. Measurement of social entropy, according to the principles of Spiral Management, allows it for the first time.

The social system represents an energy of the company, which is supplied in the process by its staff. The social system is a living, open system which is not subject to classical laws of thermodynamics, but Prigogine laws. Entropy of social systems expresses the disorder of social energy.

Each person or company employee, has a certain amount of his or her life energy. One can prove that every living system may be in one of five energizing conditions.(KREMPASKÝ J. 2010) These five energy states can be characterized as follows:

I. Creator - changes the system towards higher efficiency by changing its parameters

II. Innovator - increases system performance within existing parameters

III. Professional - achieves planned performance within existing parameters

IV. Slacker - does not achieve targeted performance

V. Destructor - destroys existing system

By measuring the proportion of company employees in each energetic state it is possible to determine the amount of entropy in the social system of company - social entropy $e_{s}$. (KOPČAJ A. 2007).

To determine the quality of the social system spiral management uses the parameter HRR (KOPČAJ A, 2007) - an abbreviation of Human Resources Ratio. It is calculated on the basis of identifying energizing states in the company as the ratio of the sums of states that accelerate the organization, and those that hinder the organization.

HRR = (I+II) $/($ IV+V)

for HRR $<1$ the social system acts as a mechanic system.

for HRR > 1 the social system acts as biological system. 
Unique identification of the level of the social system allows management to predict its behavior and to choose the most appropriate tools and procedures for its management. Improper management tools used do not correspond to the real level of social system and never produce the desired effects in practice (KOPČAJ A. 2007). This is the most common case of management failures at present.

\section{Methodology of research}

A manufacturing organization in the chemical industry, which has about 350 employees, was used as an example of the measured data. The company's management needed a system to estimate the necessary commitment, risks and chances of success before the introduction of Toyota system. (BorKowsKI S., STASIAK-BETLEJEWSKA R. 2014.), (SELEJDAK J. 2013): To identify the initial state of the system and its readiness the managers made use of the spiral management approach.

Figure 1 shows the measured values of energizing states of workforce. We see that almost $50 \%$ of employees are in neutral energy state III, $30 \%$ of employees are in a state I and II, that is, in states that increase the energy of the system and the remaining $20 \%$ is in the state IV and V, that is, states that reduce the energy in the system.

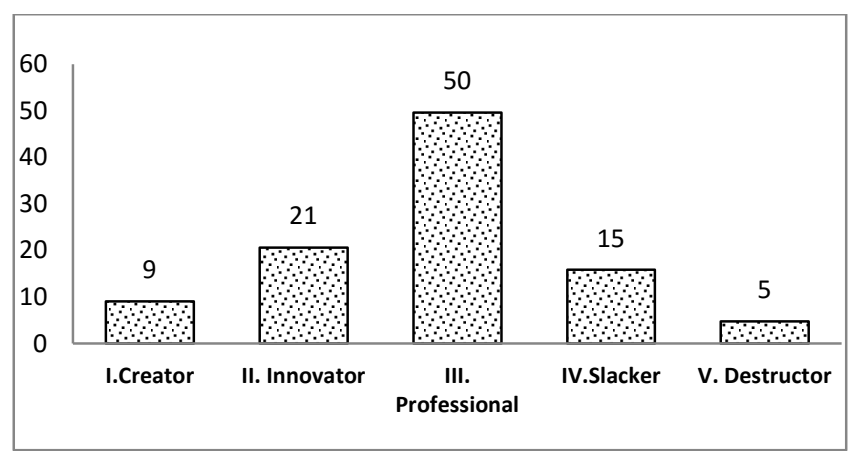

Fig.1. The social system energetic levels.

Source: author's processing

Based on this data the value of HRR, and consequently the value of social entropy of the system can be calculated

Inertia $=$ level III $=50 \%$

Dynamics $=(\mathrm{I}+\mathrm{II})-(\mathrm{IV}+\mathrm{V})=9 \%$

$\mathrm{HRR}=(\mathrm{I}+\mathrm{II}) /(\mathrm{IV}+\mathrm{V})=1,44$ $\mathrm{e}_{\mathrm{s}}=0,47$

$e_{s}-$ social entropy calculated according (KOPČAJ A. 2007)

When identifying the state of the technical system in the company, the level of entropization was measured, hence malfunction of the three essential processes in the company. The measured value entropy in processes $\mathrm{e}_{\mathrm{p}}=0.43$.

Based on the data collected and identifying the initial state of the system, it can be said that social entropy in the system exceeds the technical entropy. The company should preferably start to manage a system which is characterized by higher entropization. Therefore, also in this case, the measurements focused on human capital management were proposed to the managers.

HRR $=1,44$ indicates that the social system sometimes behaves as a mechanic but sometimes already has biological traits. The dynamics of the group, however, is weak and not enough for the successful implementation of the system. This will put increased demands on management.

The company's management was recommended to significantly reduce the entropy of the social system before starting the implementation of Toyota. Executives appreciated that they know in what state they have their people, how much energy must be spent for a successful implementation and what results can be expected.

\section{Results and discussions}

Spiral management utilization to assess the state before the implementation has proved to be successful. The data obtained has sufficient explanatory power for managerial conclusions and significantly affected management decisions within the company. The prediction that the measurement and management of the social system greatly increases the chances of responsible decisions before implementing the new system proved accurate.

\section{Summary and conclusions}

The present paper is used to draw attention to the scientific and professional public to the existence of new, interesting and in practice, a successfully imple- 
mented approach to the managing of companies. In Poland, Spiral management is a fundamentally new approach to management that is built on respect for the laws of nature accompanying the spontaneous growth of the living and non-living systems.

Based on the data presented, it can be concluded that the measurement of the energetic states of employees, from which it is possible to determine the value of the internal entropy in a company, provides a quantifiable and sufficiently accurate and repeatable basis of data that is useful for identifying the initial state of human capital in the company and to set the appropriate set of energizing tools that really effectively cultivate social capital in the company. This approach opens up new possibilities to increase efficiency and productivity in companies.

\section{Acknowledgement}

This publication has been prepared as a partial output in the research project VEGA 1/0055/13 ,Systematization of the impact of factors and conditions of knowledge management in the context of business strategy on work incentives and its reflection in growth efficiency, respectively sustainable level of business activity“.

\section{Literature}

1. BondareVA, I.,TOMlain, J., ReCiCAR, J., 2013. Interdisciplinary Education in Management at the Technical University. In: WCLTA-2013, Barcelona 27.-29. October, 2013. Elsevier Ltd., č. 141, 2014, s. 1062 1067

2. BORKOWSKI S. 2014 : Employees satisfaction innovative approach. In: Production Engineering Archives 2 (2014)

3. Borkowski S., StASIAK-BETLEJEWSKA R. 2014. The enterprise constant improvement by using medium ratings differentiation analysis in the second Toyota principle. In: Production Engineering Archives 2 (2014).

4. DĚdKovÁ, J., SRBKovÁ, D. 2013. :Significant Competitive-ness Factors of Companies in the Czech part of the Euroregion Neisse-Nisa-Nysa, In: 8th Europen conference on Innovation and Enterpreneurship, Belgie. September 2013, s. 212-220 volume 1

5. KOPČAJ, A. 1999. Managing of curent of changes (Řizení proudu změn.) Ostrava: Silma '90, 1999.

6. KopČAJ, A. 2007. The Spiral management. (Spirálový management.) Praha: Alfa Publishing, 2007.

7. KOPČAJ, A. 2010. 7 steps to exceptionality (7 kroků $k$ výjimečnosti.) In: Management a komplexita. Ostrava: TU Ostrava -CPIT, 2010.

8. KREMPASKÝ, J. 2010. Self-development and management (Samovývoj a manažment). In: Management a komplexita. Ostrava: TU Ostrava -CPIT, 2010.

9. PlCHOVÁ, J, 2012. Measurement of the human potential by means of the internal entropy in the firm. In: Problems of management of 21 st Century, 5/2012, scientific methodical centre „Scientia Educologica"Lithuania 2012.

10. PlchovÁ, J., Polakovič, L'. 2015.:Quantification of the Human Resource Management- Spiral Management. In: Strategic management 2015: XI International May Conference on Strategic Management. University of Belgrade, Technical faculty in Bor, Bor May 2015.

11. SELEJDAK J. 2013: Use of the Toyota management principles for evaluation of the companyś mission. In: Production Engineering Archives 1 (2013).

12. Š́́BERTOVÁ, E. 2014. Activities of cooperatives in Slovakia during economic crisis. In: MANEKO Journal of Corporate Management and Economics 1/2014.

13. ZATrochovÁ, M., HerZKA,P.,2011. Factors influencing the satisfaction ofemployees on managing the decision-making process in the company. In:Toyotarity: Elements of the organization's mission, Dnipropetrovsk 2011. 